\title{
In Vitro Evaluation of Antioxidant Properties of Ten Iranian Medicinal Plants
}

\author{
Mahmoud Rafieian-Kopaei ${ }^{1, *}$ \\ ${ }^{1}$ Medical Plants Research Center, Shahrekord University of Medical Sciences, Sharekord, IR Iran \\ ${ }^{*}$ Corresponding Author: Mahmoud Rafieian-Kopaei, Medical Plants Research Center, Shahrekord University of Medical Sciences, Sharekord, IR Iran. Tel: +98-9131811842, Fax: +98- \\ 3813330709, E-mail: rafieian@yahoo.com
}

Received: January 13, 2013; Revised: August 5, 2013; Accepted: March 15, 2014

Keywords:Antioxidant; Evaluation; Plants, Medicinal

\section{Dear Editor,}

We read with interest the recently published article in the esteemed Iranian Red Crescent Medical Journal, by Moein et al., entitled "In vitro antioxidant properties evaluation of 10 Iranian medicinal plants by different methods"(1) in which antioxidant properties of ten Iranian medicinal plants were evaluated with two reliable models. The authors found very high levels of phenolic compounds and antioxidant activities in Verbascum sinuatum L. and Rosa damascena Mill so that the antioxidant activities in terms of 1,1-diphenyl-2-picrylhydrazyl (DPPH) radical scavenging model in $V$. sinuatum $\mathrm{L}$. $\left(\mathrm{IC}_{50}=263.52 \pm\right.$ $5.981 \mu \mathrm{g} / \mathrm{mL}$ ) and R. damascena Mill $\left(\mathrm{IC}_{50}=287.9 \pm 5.675 \mu \mathrm{g} /\right.$ $\mathrm{mL}$ ) were even higher than gallic acid $\left(\mathrm{IC}_{50}=25.32 \pm 5.593\right.$ $\mu \mathrm{g} / \mathrm{mL}$ ), which is usually used as a standard antioxidant. The authors have skipped from these valuable results that might have tremendous clinical implications. Most of the untreatable diseases or toxic effects of drugs are related to free radicals and consumption of antioxidants may scavenge these free radicals. It is being increasingly recognized that many of currently untreatable or hard to treat diseases are due to the "oxidative stress". Oxidative stress is initiated by free radicals and results from an imbalance between formation and neutralization of these highly active compounds. Free radicals seek stability through electron pairing with biological macromolecules such as lipids, proteins, and DNA in healthy human cells and cause lipid peroxidation along with protein and DNA damage. These changes highly contribute to the atherosclerosis, cardiovascular diseases, cancer, ageing, and inflammatory diseases (2-5). Human cells protect themselves against free radical damage by antioxidant compounds such as ascorbic acid, tocopherol, and glutathione or enzymes such as catalase and superoxide dismutase (6-8). These protective mechanisms might be disrupted by various pathological processes. In these situations, antioxidant supplements are vital to combat oxidative damage (6-8). Recently, high attention has been directed towards the ethnomedicines with strong antioxidant properties but low toxicities. Although, in Moein et al. article, (1) the extracts were not examined for different reactive oxygen species such as "singlet oxygen, superoxide, hydrogen peroxide, hydroxyl, nitric oxide and peroxynitrite", total antioxidant activities were examined and showed to be very high for V. sinuatum L. and $R$. damascena Mill. Plants with antioxidant activities have shown promising results in various conditions including prevention or treatment of hyperlipidemia (9), diabetes (10), cancer (11), ischemia, and inflammatory diseases (4). These plants have also protective effects against toxicity of different drugs (12-15). Therefore, the plants $V$. sinuatum L. and $R$. damascena Mill, which have high levels of antioxidants, are promising and worth examining for the conditions that cause extensive damage to tissues and biomolecules leading to various disease conditions, especially degenerative diseases and lysis degeneration.

\section{References}

1. Moein S, Moein M, Khoshnoud MJ, Kalanteri T. In vitro antioxidant properties evaluation of 10 Iranian medicinal plants by different methods. Iran Red Crescent Med J. 2012;14(12):771-5.

2. Behradmanesh S, Derees F, Rafieian-kopaei M. Effect of Salvia officinalis on diabetic patients. J Ren Inj Prev. 2013;2(2):57-9.

3. Tavafi M. Protection of renal tubules against gentamicin induced nephrotoxicity. J Renal Inj Prev. 2012;2(1):5-6.

4. Maxwell SR. Prospects for the use of antioxidant therapies. Drugs. 1995;49(3):345-61.

5. Rafieian-Kopaie M, Baradaran A. Teucrium polium and kidney. J Renal Inj Prev. 2013;2(1):3-4.

6. Niki E, Shimaski H, Mino M. Antioxidantism-free radical and biological defense. Gakkai Syuppn Center.1994:3-16.

7. Nasri H. On the occasion of the world diabetes day 2013; diabetes education and prevention; a nephrology point of view.J Renal Inj Prev. 2013;2(2):31-2.

8. Tavafi M. Diabetic nephropathy and antioxidants. J Nephropathol. 2013;2(1):20-7.

9. Khajehdehi P. Turmeric: Reemerging of a neglected Asian traditional remedy.J Nephropathol. 2012;1(1):17-22.

10. Rafieian-Kopaei M, Baradaran A. Teucrium polium and kidney. $J$ Renal Inj Prev. 2012;2(1):3-4.

11. Shirzad H, Taji F, Rafieian-Kopaei M. Correlation between anti-

Copyright (c) 2014, Iranian Red Crescent Medical Journal; Published by Kowsar Corp. This is an open-access article distributed under the terms of the Creative Commons Attribution License, which permits unrestricted use, distribution, and reproduction in any medium, provided the original work is properly cited. 
oxidant activity of garlic extracts and WEHI-164 fibrosarcoma tumor growth in BALB/c mice. J Med Food. 2011;14(9):969-74.

12. Nasri H, Shirzad H. Toxicity and safety of medicinal plants. HerbMed Plarmacol. 2013; 2(2):21-22.

13. Rafieian-Kopaei M, Nasri H. Ginger and diabetic nephropathy. $J$
Renal Inj Prev. 2012;2(1):9-10.

14. Rafieian-Kopaei M, Baradaran A, Rafieian M. Plants antioxidants From laboratory to clinic. J Nephropathol. 2013;2(2):152-3.

15. Nasri M H, Rafieian-Kopaie.. Silymarin and Kidney.J Renal Inj Prev. 2012;1(1):3-6. 